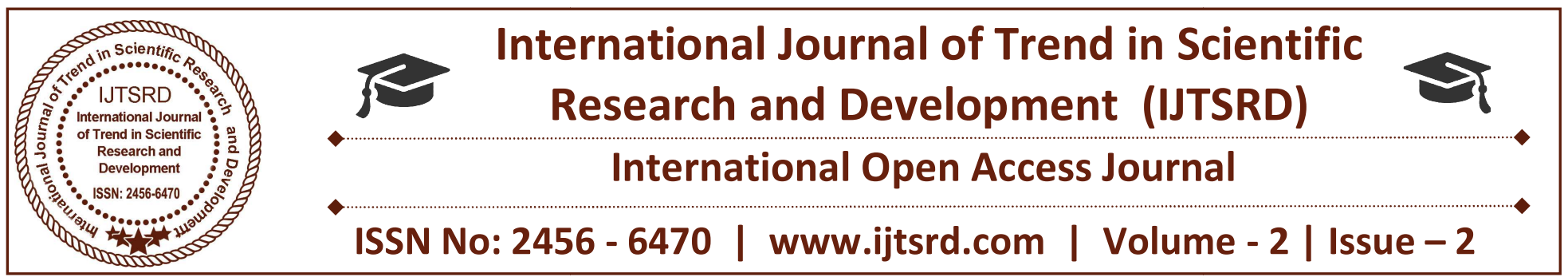

\title{
The Mythical Matrix of the Santals (A Key to entry into a tribe dispersed in many states of North India)
}

\author{
Vijay Kerketta \\ Asst. Porofessor \\ St.Mary's, Malda, West Bengal, India
}

\section{INTRODUCTION}

The Santals are tribals ${ }^{1}$. L. O'Mally writes, "This tribal community even today consists of one of the largest, most cohesive and resilient tribes in eastern

\footnotetext{
${ }^{1}$ There is no exact definition of who a tribal is. Hence, there is a need to understand what a tribe is so as to fathom who a tribal will be. According to G. Marshall, the term tribe "usually denotes a social group bound together by kin and duty associated with a particular territory. Members of the tribe share the social cohesion associated with the family, together with the sense of political autonomy of a nation" (cf. G. MARSHALL, Oxford dictionary of sociology, Oxford University Press, Oxford 1998, p. 674). R. C. Verma defines the tribes thus. "At present, the term tribe, according to western writers, generally means an ethnic group, geographically isolated or semi isolated, identified with one particular territory and having distinct social, economic and cultural traditions and practices. In the Indian context the term has undergone further change, particularly in postindependence period" (cf. R. C. VERMA, Indian tribes through the ages, Ministry of Information and Broadcasting, Government of India, New Delhi 2002, p. 9). S. Hans offers a pertinent clarification from the point of view of Governement as well as who tribals exactly are in a given region with their given profession as he argues, "The word tribal refers strictly speaking to those ethnic groups, that are listed in the Constitution of India as Scheduled Tribes (ST). During several centuries however, other population groups, such as some Scheduled Caste groups, or backward communities have lived in symbiosis with the tribals, such are the Mahatos (vegetable growers), Kumhars (potters), the Lohars (blacksmiths), the Turis or Mahalis (basket weavers). Culturally and racially, they form a continium with the ST groups and are in the present document, considered as being a part of indigenous population of Chotanagpur, without being tribals" (cf. S. HANS, Tribal culture and identity in Chotanagpur: challenge before higher education, Jojohatu House, Ranchi 1986, p. 3). Dr. V. C. Sharma gives a splendid description of the 32 tribal groups of Jharkhand, their number, their characteristics, religions and the name of the Supreme
}

India. They have certainly been the most written about in song and literature beginning from the days of the Raj",2. They understand the world in terms of relationship. They are convinced that the world and all that is in are made for use and not for abuse, for sustenance and not for dominance. Fraternal coexistence is preferred over fraternal quarrel and tension. Hence, N. Minz, a tribal himself, witnesses about them in these words, "Nature, human beings and spirits are dependent on each other as organisms. Land, forest, water and air are God-given with no ruler or national government having proprietary ownership of them. Human beings are custodians of everything around them and must relate with everything as a relative and friend, and live in harmony with them"3.

The Santals have a culture of their own which they have preserved unchanged from time immemorial. Until recently, the Santal society has not faced with any invasion- cultural or religious, etc., either from within or without. They have, so far, enjoyed both external and internal autonomy concerning their religiosity and world-view, which have remained unaltered and unquestioned. Their religious life and cultural festivals, mainly connected to nature and agriculture, are so attractive that many, both from the homeland and abroad, have written books and articles

Deity according to every tribe (cf. V. C. SHARMA, Jharkhand ki janjatiyan, Crown Publications, Ranchi 2006, pp. i-xxvi).

${ }^{2}$ L. S. O’Mally, Bengal district gazetteers: Santal Parganas, Logos Press, New Delhi 1910, see the left flap.

${ }^{3}$ N. MinZ, "Tribal theologies", in V. FABELLA (ed.), Dictionary of third world theologies, Orbis Books, New York 2000, p. 229. 
depicting various aspects of them in an attempt to understand and appreciate them better. No wonder why, until 1979, sixty-seven books and 259 articles are written exclusively on the Santals. Out of 67 books, the foreigners (British high officials and Christian missionaries) alone wrote 62 books and 97 articles before the independence of India on August 15, 1947. After the independence, until 1979, five books and all the rest of the articles have been written by Indian anthroplogists and sociologists ${ }^{4}$. After 1979 until date, quite a few books and quite many articles have again been written on them.

Every society, "advanced" or "primitive", has an anthropological, sociological, political, theological or other dimension to it. There are authors who have closely followed and narrated relating and pertaining to their social, anthropological and political characteristics but not many have attempted to decipher the deeper dimension of the Santals. This article will, therefore, make a humble attempt to peep into their inner cravings and search for meaning. To do so, one must enter into the world view of the Santals: their conception of the world and its origin, their anthropology, their sociology and their eschatology. At the outset itself it may be made clear that this article will deal mainly with the faith aspects of the Santals, what they believe in, what are their convictions through which they operate and pursue their life journey. The theologizing process will then depend heavily on the social and anthropological dimension of the Santals on which quite a few books have been written. To begin with, this article will unfold itself in discovering the Santals as the theological people. Their origin and migration, their way of understanding the world and its courses will manifest their deep-seated desire to seek union with God, unity among themselves and harmony with the nature.

\subsection{Hypothesis concerning the origin and history of the Santals}

The Santals themselves have no written records of their own. Hence, it is not easy to determine the exact time and place of their origin. Inasmuch as the history of their origin is obscure, nothing can be said with certainty regarding their migration too. No one knows for sure whether India is their homeland from all eternity or they pitched their tent in India. If their

\footnotetext{
4 J. TroIsI, "Introduction", in J. TroISI (ed.), The Santals: readings in tribal life, vol. $\mathrm{X}$, Indian Social Institute, New Delhi 1979, pp. x-xiii.
}

origin was elsewhere, the question then arises from where, when and how they came to India? Some scholars opine and argue that they had been in India before the Aryans arrived in India ${ }^{5}$. If anyone asks them their origin they casually and simply tell them that they came from the land of Hihiri Pipiri through a mountain pass and thus forgot the date ${ }^{6}$. Hihiri Pipiri calls for different interpretation according to different authors. According to P. O. Bodding, Hihiri Pipiri is the cradle of human race $^{7}$ whereas A. Campbell in his Santali-English dictionary writes Hihiri Pipiri to be "The traditional home of the Santals where the first man and woman lived" 8 . Most probably, argues V. M. Raj that Hihiri Pipiri is a mythical name that refers to a flourishing place. He believes that, "According to their tradition, their ancestors came to this land as immigrants from the "Champa Disom" (probably the country which lies to the north-west of the Chotanagpur Plateau)" . Concerning their past history, the Santals remember two folksongs which sound as though they were their credo. The first one is positive; it recalls their primal history, as it were:

Hihiri Pipiri rebon janam lena (We were born at Hihiri Pipiri)

Khoj Kaman rebon khoj lena (We were called for at Khoj Kaman),

Harata rebon haralena (We grew up at Harata),

Sasan Beda rebon janalena ho (We became clans at Sasan Beda) ${ }^{10}$.

The second seems to be of a later stage and is preserved in the form of a lament:

Champa gar do lilibici (Fort Champa was ornamental)

Badoli Koenda likhan gorhon (Fort Badoli Koenda was decorative)

${ }^{5}$ J. GAUSDAL, Journal of the Asiatic Society Science, vol. XIX, 1953, p. 3.

${ }^{6} \mathrm{M}$. PEDERson, In the land of the Santals, The Messenger Press, Minnesota 1952, p. 8.

${ }^{7}$ P. O. Bodding, A Santal dictionary, vol. III, I Kommisjon Hos Jacob Dynard, Oslo 1935, p. 115.

${ }^{8}$ A. CAMPBELL, A Santal-English dictionary, The Santal Mission Press, Manbhum 1899, p. 230.

${ }^{9}$ V. M. RAJ, A Santal theology of liberation, Uppal Publishing House, New Delhi 1990, p. 1.

10 T. HEMBROM, The Santals: anthropological-theological reflections on Santali \& biblical creation traditions, Punthi Pustak, Calcutta 1996, p. 8. 
Daeage Champa, Badoli Koenda (Oh! Champa and Badoli Koenda)

Daeyage gar bon bagiada (Alas! we left our forts) ${ }^{11}$.

\subsubsection{Further hypotheses about their origin and migration}

It has so far been impossible to state their origin with certainty, but it is generally acknowledged that they were inhabitants of India before the Aryans invaded the country about fifteen hundred years before Christ. $\mathrm{H}$. Jorgensen argues that the Santals are one of the aboriginal tribes of India belonging to the so-called Munda-speaking group of people. They have been in India even before the time of Moses and that they were in the west but went on moving forward to the east, in the direction where the sun rises ${ }^{12}$. P. C. Biswas suggests that, "Revd. Skrefsrud has suggested that the Santals entered India from the North West and first settled in the Punjab and then made their way to their present habitat at Chota Nagpur. But Colonel Dalton and Sir William Hunter believed that the Santals came to the present abode from North East India" ${ }^{\prime 3}$. A. Campbell suggests:

Starting from the north-east, they gradually worked their way up the valley of the Ganges till we find them in the neighbourhood of Benares, with their headquarters near Mirzapur. Here the main body, which had kept to the northern bank of the river, crossed, and, heading southwards, came to the Vindhya hills. This obstruction deflected them to the left, and they at length found themselves on the tableland of Chota Nagpur ${ }^{14}$.

A few of the Indian anthropologists believe in the fact that humans first came in India about 65000-55000 years ago. The earliest of them, guesses R. R. Diwakar, were Proto-Australoids followed by the Proto Dravidians ${ }^{15}$. Diwakar then studies the comments of B. S. Guha according to whom, the earliest race which inhabited India was that of the Negritoes. The second strain was the Proto-

\footnotetext{
${ }^{11}$ N. Hembrom, Austric civilization of India, Hari Pada Sahoo, Calcutta 1982, p. 7.

${ }^{12}$ H. JORGENSEN, Evangeliet blandt Santalalerne: den nordiske Santalmissions historie, Dansk Santalmission, Kobenhavn 1940, p. 5.

${ }^{13}$ P. C. BISWAS, Santals of the Santal Parganas, Bhartiya Adimjati Sevak Sangh, New Delhi 1956, pp. 2-3.

14 Ibid.

${ }^{15}$ R. R. DIWAKAR, Bihar through the ages, Oxford University Press, Calcutta 1959, p. 70.
}

Australoid, which apparently displaced the Negritoes and probably absorbed some of their blood ${ }^{16}$. J. Gausdal, continuing in the same line as Guha, maintains that the Proto-Australoids can be distinguished with some facial characteristics such as low forehead, thick lips, wide jaw and wavy hair. Historians believe that they were the ancestors of tribal community residing in the eastern part of India (excluding hilly portions). So the Santals, Uraons, Khols and Mundas may be the descendants of them. They have a patrilineal exogamous clan organization. Because of their similarity of racial type with Australian tribes, the name given to this ancient people is ProtoAustraloid. "It is found among the prehistoric skulls in the Trinnelveli district, and from references in early Sanskrit literature to 'Nishads' where they are described as noseless (anash) with dark skin colour and peculiar speech and habits there can be no doubt that the ProtoAustraloid tribes were meant"17.

On the basis of their language and physical complexion, by way of hypothesis, some scholars categorize them under Dravidian stock, while others suggest that they are of Mongolian descent, and yet others have grouped them with Proto-Australoid tribes $^{18}$. P. O. Bodding traces out Mongolian racemarks sometimes occurring among the Santal children. He thus draws a conclusion that Mongolian blood has been introduced either by Santals taking Mongolian wives or by Santal women having illegitimate children by Mongolian $\operatorname{men}^{19}$. P. C. Biswas, after having made an anthropometric analysis of a group of Santals, concluded his analysis thus: "It is highly appropriate to suggest that the Santals who are mainly proto-Australoids also show certain Mongoloid affinities on ethnic scales which in my opinion should be thoroughly investigated in Central India",

\subsubsection{Hypothesis regarding their settlement}

They came to Chotanagpur ${ }^{21}$, the cradle of tribal

${ }^{16}$ Ibid.

${ }^{17}$ J. GAUSDAL, op. cit., p. 3.

18 Ibid.

19 O. Hodne, L.O. Skrefsrud missionary and social reformer among the Santals of Santal Parganas, Egede Institutet, Oslo 1966 , p. 18.

${ }^{20}$ P. C. BISWAS, op cit., p. 212

${ }^{21}$ Chotanagpur, also called Chotanagpur Plateau or the Plateau, denotes the hilly plateau area of the states of South Bihar and Jharkhand spilling over into the states of north of Orissa and also in parts of West Bengal and Madhyapradesh (now Chattisgarh). It is an area with a geographic as well as ethnic identity of its 
inhabitants in pre-historic India, but went on wandering due to external invasion, growing population and more so in search of a happy habitat until they settled in the Chotanagpur Plateau from where they have today dispersed to different regions and states their main focus being the Santal Parganas. S. Hans writes, "With the Chotanagpur Plateau is usually associated the Santal Parganas, another area in the Eastern part of Bihar, bordering on West Bengal. It is the homeland of the Santals, one of the largest tribes in India",22.

About their settlement, J. Troisi is of the opinion that "Whatever their original habitat might have been, authentic records show that during the $18^{\text {th }}$ century many Santals began to settle down in Chotanagpur and in the neighbouring districts of Midenapore and Singhbhum. Soon afterwards, they began to migrate to the Rajmahal Hills on the north-eastern side of the Chotanagpur Plateau"23. F. Buchanan maintains that "The Santals appear to have settled in the district around Dumka, the present headquarters of Santal Parganas, between 1790 and 1810,"24. Insofar as they are very strong, sturdy and skillful in clearing the jungles for cultivation, during the process of

own, being inhabitated mainly by tribal population (M. V. BOGAERT, "Social transformation of a tribal society", in Sevartham 11 (1986) pp. 19-37. P. TETE is still clearer in depicting Chotanagpur. He says it is called Southern part of the State of Bihar which is the habitat of the tribals. He writes, It is also called Jharkhand which comprises the districts of Ranchi, Gumla, Simdega, Lohardaga, Hazaribagh, Daltonganj, Garhwa, Chatra, Kodarma, Deoghar, Giridih, Dhanbad, East and West Sighbhum, Bokaro, Dumka, Pakur, Godda and sahibganj. The Mundas, Uraons, Kharias, Hos and the Santals are the inhabitants of these areas of Chotanagpur (cf. P. TETE, "The Christian mission and the tribal identity", in Sevartham 24 (1999), p. 37. M. Banerjee proposes several mythical propositions and hypothesis behind the name Chotanagpur. $\mathrm{He}$ also describes its geographical area, natural resources, the people, its history and the like (cf. M. BANERJEE, An historical outline of pre-British Chotanagpur, Education Print, Ranchi 1993, pp. 1-15). S. Navarangi maintains that the Aryans called it Jharkhand (cf. S. NAVRANGI, Chotanagpur ka sanchipt itihas, Sinha Press, Ranchi 1948, p. 1).

${ }^{22}$ S. HANS, op. cit., p. 2.

${ }^{23}$ J. TROISI, op. cit., P. 1. But the fact that they settled down in Chotanagpur only during the $18^{\text {th }}$ century looks rather less probable. It could even be questionable. For when one sees the Santal Insurrection against the British in 1855 it makes one think that if they had been so recently settled in Chotanagpur Plateau, they would not have thought of uniting themselves against the sophisticated British army. Moreover the British and the missionaries, on their arrival during $19^{\text {th }}$ century, found the Santals well settled in the land.

${ }^{24}$ F. BUCHANAN, An account of the district of Bhagalpur in 1810-11, Patel \& Co., Patna 1939, p. 264. settlement at above said places, they cleared the virgin forests while fighting with the wild beasts, serpents and scorpions. They turned them into the cultivable land and were the original settlers. Hence they can rightly be called aboriginals ${ }^{25}$.

There are others who maintain that the Santals are an advanced non-Aryan tribe. They are simple and hospitable by nature ${ }^{26}$. They are the single largest indigenous group with a homogeneous society inhabiting the northern part of India numbering about 5 million $^{27}$. However, there are scholars who do not agree that they are the largest tribe but 'only merely large ${ }^{28}$, or the 'second largest tribe of India' 29 . Then there are some who conclude that the Santals are only the third largest tribe of India ${ }^{30}$. Today they are found spread over in the states of Jharkhand, West Bengal, Orissa, Bihar, Assam, Meghalaya, and Tripura and outside India, in Bangladesh, and of course a small minority, in Nepal and Bhutan too ${ }^{31}$. V. N. P. Sinha

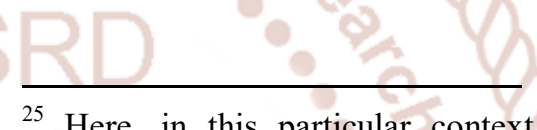

25 Here, in this particular context, the word "aboriginal" is preferred as against "indigenous" because though they are the first and original settlers in the land which they now possess, their origin is definitely elsewhere. Even their oral tradition which they preserve suggests that they are the immigrants in their present habitat. They can be graded as indigenous aboriginals only insofar as they cohabit with other tribals like Maler and Paharia, and Hindu and Muslims. But in true sense of the word indigenous, they are only the aboriginals. Others call them indigenous, aborginals, tribals, natives or Adivasis which does not give them their total identity. Their total identity is that they are Hor $\square$ (Santals) in the case of the Santals. In the case of the Uraons, they call themselves Kurux. Mundas and Kharias call themselves Munda and Kharia respectively. Henceforth when the word tribals is used, it will denote all the different tribes collectively.

26 J. BENJAMIN, "Our story: history of Dumka-Raiganj Province", in In the footsteps of the founding fathers, 31 May to 2 June 2006, p. 64

27 J. PeArSAll, "Santals", in J. PEARSAll (ed.), Oxford dictionary of English, Oxford University Press, London 2005, p. 1564. V. N. P. SINHA - L. K. P. SINGH make mention of 30 different tribes living in Jharkhand and show that according to the census of 1981 the Santals alone contribute $34.16 \%$ of the total tribal population (V. N. P. SinHA - L. K. P. SingH, Jharkhand: land and people, Rajesh Publications, New Delhi 2003, pp. 212-213).

${ }^{28}$ G. S. Ghurye, The scheduled tribes, Popular Book Dept., Bombay, 1959, p. 212.

${ }^{29}$ V. KOCHAR, Social organization among the Santals, Editions Indian, Calcutta 1970, p. 1.

$30 \mathrm{Cf}$. Sharkhand at a glance, CCBI $17^{\text {th }}$ plenary assembly, Ranchi, March 4 to March 8, 2005, Kailash Paper, Ranchi 2005, p. 6

31 J. TROISI, The Santals: a classified and annotated bibliography, Manohar Publications, New Delhi 1976, p. 1. 
and L. K. P. Singh maintain that they are found in a few numbers in China as well ${ }^{32}$.

\subsection{The name Santal}

The word Santal is found spelled in different ways as Saontar, Sonthal, Sontal, Santhal and Santal. The last form of spelling is used commonly by more recent writers on the Santals, and also by P. O. Bodding in his Santali dictionary ${ }^{33}$. The word Santal, according to some, derives from the land of Saont in the Midnapore district of West Bengal, which they occupied for agrarian purposes ${ }^{34}$. But it conceals more than it reveals, for it keeps the reader in suspense about what they were called before they came to Saont. Most probably others have given them the name of Santals. But if one asks a Santal to designate himself, he will at once assert that he is a Hor-hopon, which means he is a son/child of man, or a human being. When he asserts that he is the son/child of man (hor-hopon), he does not negate the identity of the other nor does he criticize or depreciate others. He only wishes to convey that he is fortunate to be a Hor (Santal). These aboriginals belong to yet another aboriginal tribe known as the Mundas but like to call themselves Hor ${ }^{35}$, which denotes both the people (collective or/and individual) and their language ${ }^{36}$.

However, in government circles they are known as Santals/Santhals and their language (Santali ${ }^{37}$ ) is believed to be one of the oldest languages spoken in India. Since 2005 it is no more a dialect as Indian Government accepts it as one of the recognized languages. Scholars categorize it among the Kolerian family of languages but there are more scholars who agree with the fact that Santali belongs to the Munda

\footnotetext{
${ }^{32}$ V. N. P. SINHA - L. K. P. SINGH, op. cit., p. 214.

${ }^{33}$ O. HODNE, op. cit., p. 9.

${ }^{34}$ V. M. RAJ, op. cit., p. 1.

35 A. GHosh, Santali: a look into Santal morphology, New Delhi: Gyan Publishing House, 1994, p. 2. According to J. B. Hoffmann, the name Munda, the tribe of which the scholars opine the Santals have some affinity, seems to have been given to the people of Munda tribe by their Hindu neighbours and by the British rulers. The Mundas called themselves 'horo-ko' (people) and their race 'horo' (man). They had no objection however to being called Mundas, for in their language it means chief or headman. (cf. J. B. HOFFMANN, Encylopaedia mundarica, vol. VIII, Gyan Publishing House, New Delhi 1998, p. 2338 .

36 J. LAKRA, "Rewriting tribal anthropology", in Sevartham (22) 1997 , p. 12.

${ }^{37}$ J. PEARSALL, op. cit., p. 1564. He categorizes Santali as "The Munda language of the Santals, with over 3 million speakers".
}

group of languages ${ }^{38}$. Hor or Santali does not have a commonly accepted script of its own. "Though more people use Roman script, in some parts Olchikki and in some other places Devnagiri are used to write the language, 39 . The Santali script Olcemet or Olchikki is alphabetic and does not share any of the syllabic properties of the other Indic scripts such as Devanagri. It uses 30 letters and five basic diacritics. It has 6 basic vowels and three additional vowels, generated using the Gahla Tudag (gutterals). Olchikki is believed to be invented and devised by Pandit Raghunath Murmu in 1925. He wrote over 150 books covering a wide spectrum of subjects such as grammar, novels, drama, poetry and short stories in Santali using Olchikki script with the view of propagating Santali language and to uplift the Santal community ${ }^{40}$. "But somehow", argues L. Tirkey "It could not be very popular, as Santals spread over Bihar, West Bengal and Orissa adopted scripts like Devnagri, Bengali and Oriya in the respective States in addition to Roman script"41. Tirkey's opinion could be debated because after 2000, it has been observed that Olchikki has been given due importance by West Bengal and Jharkhand Governments. Many primary schools have been opened in aforesaid states where the medium of instruction is Olchikki.

\subsubsection{The Santals: A people discovered by the Protestant missionaries}

Ever since the British rule over India, and the Santal Rebellion of 1855 , the entire tribe has been a kind of national hero. After the Rebellion, the district of Santal Parganas ${ }^{42}$ was formed, and since then the

${ }^{38}$ T. SCHREIBER - H. FRIESE, Atlantis weltatlas, Paul List Verlag, Munchen 1984, pp. 174-75. In fact, Mundari, Santali and Ho are sister languages just as one finds Bengali, Assamees and Uria in north India and in Europe Italian, French and Spanish.

${ }^{39}$ J. BENJAMIN, op. cit., p. 65.

40 "Santali language and anthropology" in

http://en.wikipedia.org/wiki/Santals.

${ }^{41}$ L. TIRKEY, Tribals, their languages and literature, Don Bosco Publishers, Ranchi 1998, p. 21.

${ }^{42}$ The Santal Pargana/Parganas denotes a piece of 14,306 square kilometers land in the northern part of India, (cf. J. NYHARGEN, Santal missionens historie, med saerlig henblikk pa utviklingen India og Norge 1867-1967, Bind I, Den Norgke Santalmissjon, Oslo 1967, p. 17) now spread over in the states of Jharkhand and Bihar comprising six civil districts: Deoghar, Dumka, Godda, Jamtara, Pakur and Sahibganj. But in those days, it was one single district. That apart, in some places, instead of the Santal Parganas, one finds yet another name as well, namely Damin- $i$ koh meaning hill-skirts. There are minor differences in the exact measure of the land as given above. However, the majority give 
Santals of these particular districts have enjoyed special legislative protection and have attracted to them the British and the missionaries alike ${ }^{43}$. When L. O. Skrefsrud, a Norwegian German Evangelical Lutheran Missionary, born on February 4, 1840, as the fifth child of a poor tenant farmer in Gudbrandsdalen, Norway, arrived in the Santal Parganas in 1866, the Santals were in a state of disintegration. If anyone ever needed someone to fight their case, it was the Santals, and no one could have been more capable of doing this than the Skrefsrud who felt that he was a chosen instrument of a Higher Power to guide the Santals for the purpose of effecting their spiritual transformation and their social advancement ${ }^{44}$. The pioneer German Evangelical Lutheran Missionary, in one of the Annual reports himself writes, "Early in the year 1866 we came to the resolution, after mature thought and consideration, of devoting our lives to independent mission operating among the Santals" ${ }^{\prime 4}$. O. Hodne bears witness to the work of the pioneers:

In 1867 Skrefsrud, together with his British colleague Mr. E. G. Johnson and his Danish colleague Mr. H. P. Boerresen founded the Ebenezer Mission Station in Santal Parganas and established work under the name of the Indian Home Missions to the Santals (IHM). In 1910 the official name of the Mission was changed to the Santal Mission of the Northern Churches. A shortened form, the Santal Mission (SM) is also often found ${ }^{46}$.

A decade later Mr. H. P. Boerresen, the pioneer mission companion of L. O. Skrefsrud, in one of the annual reports of the Santal Mission writes:

A few days subsequently Mr. Skrefsrud and I went to Nya Dumka to get the lease of the new Station there, and to start the preparation for building the new mission house. It is a lovely spot surrounded by hills

the figure cited above. Then there are others who come up with some further specification of the Santal Parganas. For example, L. S. O'Mally furnishes still clearer definition of the Santal Parganas in pre-independent India. "Santal Parganas comprised the area bounded in the north by the districts of Deoghar and Purnea in present day Bihar; on the eastern side by Birbhum, Murshidabad and Malda; on the southern boundary by Burdwan and Manbhum; and in the west by Hazaribagh and Bhagalpur" (L. S. O'MALLY, op. cit., see the flap).

${ }^{43}$ O. HODNE, op. cit., p. 9.

${ }^{44}$ Ibid., p. 34.

${ }^{45}$ L. O. SKREFSRUD, The tenth annual report of the Indian home mission to the Santals for the year 1876-1877, 20 British Indian Street, Advertiser Press, Calcutta 1878, p. 1.

${ }^{46}$ O. HodNE, op. cit., p. 9. and forests, but we anticipated very uphill work there, as the Santals who live close to Dumka have learnt all the bad habits of the Hindus there, and hence they seem to be worse than even the Hindus themselves. But as we believe and know that the Lord Jesus has not sent us to the best people but even the very worst and lowest, we hope by faith and His grace to go forward there without fear to bring these poor lost sheep unto Him. The Santals living at a little distance from Dumka, a very large population, are more genuine, and consequently more simple and easier to deal with, and if only we have the right man for that district, we are sure there will be a rich harvest sooner or later ${ }^{47}$.

It is sheer unjust to give only a briefest account, as has been furnished above, of what the Protestant Pioneer Missionaries have done among the Santals but for given the subject matter, only so much could be afforded for now. It is needless to say that the entire Santal society will remain ever grateful to the Protestant Missionaries who have contributed so much for its transformation and advancement in all spheres of life.

\subsubsection{Catholic missionaries among the Santals}

The 'Santal Mission' proper, by the Catholics, began quite a few years later when compared to the Protestants. Fr. L. Knockaert, SJ had pioneered in the 'Jhargram Mission' 48 from 1885 to 1895 succeeding another pioneer, Fr. Schaff, a German Jesuit. Apparently, due to his doubts about the solidity of his catechumens, his Superiors removed him from Jhargram and put him at Morrapai ${ }^{49}$. In 1900 he was sent to Purnea in Bihar. When at Purnea, Fr. Rocca, his Italian neighbour from Dinajpur (now Bangladesh), wrote to him in December 1912 informing him about the Santals of Dinajpur district who had migrated and settled themselves at Kishenganj, Bihar. Fr. Knockaert visited them at once. And there he became a hero among the Santals intervening them in cases of land oppressions by Muslim zameendars (landlords) ${ }^{50}$ :

\footnotetext{
${ }^{47}$ H. P. BOERRESEN, The eleventh annual report of the Indian home mission to the Santals for the year 1877-1878, 20 British Indian Street, Advertiser Press, Calcutta 1878, p. 46.

${ }^{48}$ Jhargram is the name of a place in the district of Midnapore, West Bengal, India.

49 Morrapai is the name of a place in the district of South 24 Parganas, West Bengal, India.

50 Y. de SteEnhault, History of the Jesuits in West Bengal 1921-1985, Catholic Press, Ranchi 1990, pp. 58-59.
} 
In November 1916, Archbishop Meulman had taken Knockaert seriously and spent one full week touring the "Santal Mission" with him. He was impressed, but resources both in men and money were at a low ebb during the War years. For the sinews of war however, the booklets "Four Mission tours among the Santals," were rapidly through two editions, the Calcutta public and the Purnea planters helped generously. With the help of catechists recruited and 'trained' locally, by 1920, 889 Santals were baptized and there were 3003 catechumens $^{51}$.

From Majlishpur ${ }^{52}$, the Catholic missionaries slowly but steadily, set their foot towards the central district of the Santal Parganas where the Santals are most numerous. "The Archbishop of Calcutta, Mgr. Ferdinand Perier, SJ wanted the Jesuits to move into Santal Parganas. The task of pioneering was entrusted to Fr. Benjamin Gauchi, SJ who arrived at Pakur railway station on $7^{\text {th }}$ January 1930 " 53 . Side by side, and hand in hand of course, the Protestant and the Catholic missionaries thoroughly involved themselves into the lives of the Santals in an attempt to transform them from every type of bondage: social, political or spiritual. Mr. Boerresen was right in his prophecy when he said sooner or later there would be a rich harvest. He was not alive to see the fruit of his own labour but anyone entering into the area where they worked will not fail to see the difference it has brought into the lives of the Santals.

\subsubsection{The mythical matrix of the Santals}

Having given a very brief introduction about the Santals, it is now time to plunge into the Santals' world of beliefs. The Santals, unlike the followers of world religions, do not have a temple to worship in; they do not have a Sacred Scripture for their reference nor do they have a religious founder. Granted that they do not have a temple, Scripture and religious founder does not necessarily imply that they are unconcerned about God question and with the question of the meaning of life. In fact, in order to comply with these, they make use of myths. Thanks to S. Konow who has done a wonderful job by publishing 93 Santal folktales in three volumes compiled by Rev. P. O. Bodding (1868-1936), a Norwegian missionary who lived and worked among

\footnotetext{
51 Ibid.

${ }^{52}$ Majlishpur is the name of a place in the district of North 24 Parganas in West Bengal. It is close to both Purnea and Kishanganj districts of Bihar, the name of the places just mentioned in this very page.

${ }^{53}$ Y. de STEEnHaUlT, op. cit., p. 60.
}

the Santals for forty long years ${ }^{54}$. He maintains that the tribes related to the Santals have contributed to the rich store of Indian traditional tales, and a careful analysis of the folk tales now published may someday lead to important results. He is convinced that "It will be easily seen that there cannot be a better or more reliable guide to the mentality of a strange people than a comprehensive collection of such tales and traditions which live on the lips and in the hearts" ${ }^{\prime, 55}$.

The questions of their existence, identity, purpose and destination have always haunted the human mind. In order to respond to these questions humans invent and discover not only something of temporal reality like science and technology, but also of spiritual reality like myths that shape their philosophy of life. The Santals too make use of various myths to drive in the different truths in the mind of the people. In this context, they make use of a myth to understand the genesis of these spiritual realities and to attribute the work of creation to God. The myths they have shape their philosophy of life that make them live, labour and carry with them their own ideas. In the course of centuries, the word myth has developed both with positive and negative meanings for different thinkers. For the purpose here, only suitable authors for the purpose will be taken into consideration. W. King opines that myth is a powerful tool to penetrate most deeply into the mind and heart of a people. "Myths are fanciful tales of primitives spun out as explanations of beginnings. Hence creation myths are rationalization of what prescientific cultures cannot understand through other 4 means" ${ }^{\prime \prime 6}$. He further acknowledges that apparently, even writers of myth recognize the impossibility of expressing the fundamentally indescribable nature of absolute beginnings and ultimate realities $^{57}$.

Arguing on the influence of myths in shaping the philosophy of life, R. Panikkar views myths as something transparent like light helping humans to look through. "Myth is that which we take for granted, that which we do not question; and it is unquestioned because, de facto, it is not seen as questionable" ${ }^{38}$. B. Kees quotes $\mathrm{K}$. Bolle who understands myth as a word

\footnotetext{
${ }^{54}$ P. O. Bodding, Santal folktales, vol. I, Gyan Publishing House, New Delhi 1997, taken from coverpage. Coverpage and preface are written by S. Konow.

${ }_{55}^{5}$ Ibid., p. VIII.

${ }^{56}$ W. L. KING, "Religion", in The encyclopedia of religion, vol. XII, Macmillan Publishing Company, New York 1987, p. 287. 57 Ibid.

${ }^{58}$ R. PANIKKAR, Myth, faith and hermeneutics, Paulist Press, New York 1979, p. 4.
} 
for a story concerning gods and superhuman beings. "A myth is an expression of the sacred in words: it reports realities and events from the origin of the world that remain valid for the basis and purpose of all there is. Consequently, a myth functions as a model for human activity, society, wisdom and knowledge" $" 59$. The narrator(s) very cleverly subject(s) the great problem of humanity to the light of revelation: creation and nature, sin and suffering, man and wife, fraternal quarrels etc., in one and the same myth ${ }^{60}$.

Perhaps on this pretext, the Santals too have two versions of creation myth. It is unclear whether or not they were aware of other such existing myths but in order to understand how the realities they daily encounter came about, they 'invented' their share of myth. One must not look for philosophical precision and scientific truth in the myth, for it does not begin with the philosophical level of thinking. R. Panikkar writes, "Myth is the salutary fasting of thinking; it liberates us from the burden of having to think out and think through everything and thus it opens the realms of freedom: not the mere liberty of choice, but the freedom of being" ${ }^{\prime \prime 1}$. The Santal creation myth carries with it the conviction that the cosmos and human beings have an origin and that Thakur Jiu (Omniscient Spirit), the attribute given by the Santals to their Supreme Deity, is the efficient cause behind it. The myth is narrated at least on two occasions: in July-August when they celebrate the feast of Hariyari (greenery) and in December-January when they celebrate the feast of Sohrae (harvest feast) after the annual harvest is over ${ }^{62}$.

The Santals have two main versions of their creation narratives. Both the versions have been collected by the missionaries. Rev. L. O. Skrefsrud in 1870-71 is said to have collected one from a guru called Kolean the elder, and is now found contained in the Santali book "Horkoren Mare Hapramko Reak' Katha" (The Book of the Ancestors) and the other is found in "Santal traditions", in Indian Evangelical Review published in 1892 by Rev. A. Campbell. Different writers thereafter have made use of these two versions and as usual with some variations ${ }^{63}$. Variations and slight deviations are unavoidable because even the most careful observer will

\footnotetext{
${ }^{59} \mathrm{~B}, \mathrm{KEES}$, "Myth an overview", in The encyclopedia of religion, vol. X, Macmillan Publishing Company, New York 1987, p. 261.

${ }^{60}$ G. Von RoD, Genesis: Old Testament library, SCM Press

Ltd., London 1961, p. 25.

${ }^{61}$ R. PANIKKAR, op. cit., p.5.

62 C. MukherJeA, The Santals, Oriental Press Private Ltd, Calcutta 1960, pp. 235, 245.

${ }^{63}$ T. HeMBROM, op. cit., p. 82.
}

have his preunderstanding and his particular idiosyncrasy which will bear the stamp of his individual mentality. However, it would be nice to present the full texts of both the versions here in order to have a clear picture of the Santal mind set and their religiosity but perhaps in another edition that could be thought of.

\section{Conclusion}

A volcanic eruption against their oppressors in 185556 (moneylenders and landlords and also against the negligence of the British Government of preindependent India towards the Santals) brought to the attention of the entire nation that there is a certain group of people called the Santals in North India. The British Government immediately took notice of who these people are. The British Rulers deployed personnel to study about them. Though rulers, they promptly intervened into their lives. In order to be of effective help to the Santals, the British Rulers invited the Christian missionaries not mainly to proselytize them but to better understand them and thus get them out of their crisis situation. This is how the Santals had the opportunity of having the Pioneer missionaries among them. In order to understand them better, the missionaries tried to study them: their origin, history, migration, settlement etc. In the meantime, the missionaries, and later on also the British High Officials, felt the need to learn more about their world-views. They also felt the need to pen down some things that hit their ears as something peculiar yet special lest it gets lost and forgotten. While the latter gave importance to their anthropological, societal, economic and political life, the former took interest into their holistic life, the slant being on the spiritual side. They found their myths as key that would reveal to something deepseated. They felt it necessary to enter into their mythical matrix so as to better understand the Santals' mind, their society, their beliefs and convictions and their relation to God.

\section{Bibliography}

[1] BANERJEE, Manohar. An historical outline of pre-British Chotanagpur, Education Print, Ranchi 1993.

[2] BENJAMIN, Joseph. "Our story: history of Dumka-Raiganj Province", in In the footsteps of the founding fathers, 31 May to 2 June 2006, p. 64. 
International Journal of Trend in Scientific Research and Development (IJTSRD) ISSN: 2456-6470

[3] BISWAS, Pratap Chandra. Santals of the Santal Parganas, Bhartiya Adimjati Sevak Sangh, New Delhi 1956.

[4] BODDING, Paul Olaf. A Santal dictionary, vol. III, I Kommisjon Hos Jacob Dynard, Oslo 1935.

[5] BOGAERT, Michael Vanden. "Social transformation of a tribal society", in Sevartham 11 (1986) pp. 19-37.

[6] BUCHANAN, Francis. An account of the district of Bhagalpur in 1810-11, Patel \& Co., Patna 1939.

[7] CAMPBELL, Andrew. A Santal-English dictionary, The Santal Mission Press, Manbhum 1899.

[8] DIWAKAR, R. R. Bihar through the ages, Oxford University Press, Calcutta 1959.

[9] GAUSDAL, Johannes. Journal of the Asiatic Society Science, vol. XIX, 1953.

[10] GHURYE, G. S. The scheduled tribes, Popular Book Dept., Bombay, 1959.

[11] HANS, Samuel. Tribal culture and identity in Chotanagpur: challenge before higher education, Jojohatu House, Ranchi 1986.

[12] HEMBROM, Timothy. The Santals: anthropological-theological reflections on Santali \& biblical creation traditions, Punthi Pustak, Calcutta 1996.

[13] HODNE, Olav. L.O. Skrefsrud missionary and social reformer among the Santals of Santal Parganas, Egede Institutet, Oslo 1966.

[14] JORGENSEN, H. Evangeliet blandt Santalalerne: den nordiske Santalmissions historie, Dansk Santalmission, Kobenhavn 1940.

[15] MARSHALL, Gordon. Oxford dictionary of sociology, Oxford University Press, Oxford 1998, p. 674.

[16] MINZ, Nirmal. "Tribal theologies", in V. FABELLA (ed.), Dictionary of third world theologies, Orbis Books, New York 2000.

[17] NAVRANGI, Sanjay. Chotanagpur $k a$ sanchipt itihas, Sinha Press, Ranchi 1948.

[18] O’MALLY, Lewis Stuart. Bengal district gazetteers: Santal Parganas, Logos Press, New Delhi 1910.
[19] PEARSALL, J. "Santals", in J. PEARSALL (ed.), Oxford dictionary of English, Oxford University Press, London 2005, p. 1442, 1564.

[20] PEDERSON, Matthew. In the land of the Santals, The Messenger Press, Minnesota 1952.

[21] RAJ, Manuel V. A Santal theology of liberation, Uppal Publishing House, New Delhi 1990.

[22] SHARMA, V. C. Jharkhand ki janjatiyan, Crown Publications, Ranchi 2006.

[23] SINHA V. N. P. - SINGH, L. K. P. Jharkhand: land and people, Rajesh Publications, New Delhi 2003.

[24] TETE, Peter. "The Christian mission and the tribal identity", in Sevartham 24 (1999), p. 37.

[25] TROISI, Joseph. "Introduction", in J. TROISI (ed.), The Santals: readings in tribal life, vol. X, Indian Social Institute, New Delhi 1979.

[26] VERMA, R. C. Indian tribes through the ages, Ministry of Information and Broadcasting, Government of India, New Delhi 2002. 